\title{
Commentary
}

\section{Tackling Forced Labor in Qatar: Is Exploitation Nearing an End?}

\author{
By Lucia Jeremiašová, Student of the International Business Law Programme \\ and Course International Labour Law and Globalisation at Tilburg \\ University, the Netherlands
}

\section{Introduction}

Since Qatar ratified Forced Labour Convention, 1930 (No. 29) in 1998, the ILO has reported regularly on its application in the country. In the first years after ratification, the observations and direct requests of the CEACR addressed to the Qatari government dealt with child trafficking, focusing on the exploitation of children as camel jockeys and a problematic law preventing public officials from resigning. ${ }^{1}$ Despite the ILO's supervisory actions, these forced labor practices and other serious abuses continued to be reported. Their number even arose after 2010, when it was announced that Qatar would host the 2022 World Cup. ${ }^{2}$

To win the World Cup bid, Qatar committed to renovate three stadiums, construct nine new ones, complete a metro system connecting them, and build approximately fifty thousand new hotel rooms. ${ }^{3}$ In response to this major construction plan, the state quickly opened for thousands of migrant workers.

1 ILO, Observation and Direct Request of the Committee of Experts on the Application of Forced Labour Convention, 1930 (No. 29) - Qatar, 91st ILC session (2003).

2 Lee Swepston, "Commentary: Concentrated ILo Supervision of Migrant Rights in Qatar," International Labor Rights Case Law 1 (2015): 319.

3 ввс Sport, "Russia \& Qatar will host the 2018 and 2022 World Cups," 2 December 2010, http:// news.bbc.co.uk/sport2/hi/football/925o612.stm. 
Most of them were subject to the sponsorship system kafala, which gave the employer almost complete control over their employment and immigration status. ${ }^{4}$ Under this system, the migrant workers were forbidden to change employers or to leave the country without a sponsor-issued exit permit. ${ }^{5}$ The ILO also observed the limited access migrant workers had to justice and the absence of penalties usually applied to those imposing forced labor. ${ }^{6}$

The United Nations examined the situation and confirmed that a large number of migrant workers were being subjected to forced labor. ${ }^{7}$ Amnesty International reported the same issues and labeled the exploitation the Qatar World Cup of Shame. ${ }^{8}$ The abuses were so serious that since 2013 all ILO supervisory procedures have been applied: regular supervision by the CEACR and CAS, a representation filed by two international trade unions, and a complaint brought by delegates to the International Labour Conference (ILC). ${ }^{9}$ Even though the complaint, which is the most serious and only rarely used procedure, was closed in 2017 , it is still essential to observe the unclear situation in the country. In its most recent observation, the CEACR presses the government again to ensure appropriate legal framework and law enforcement.

\section{Strengthening the Legal Framework}

Within the technical cooperation program, prepared by the ILO and the government of Qatar, two legislative amendments aiming to dismantle the kafala system were drafted recently. First, Labour Act No. 14 of 2004 was amended by the Decree Law No. 18 of 2020, which allows the workers to change employers during the probation period, provided they notify the current employer at least one month in advance. ${ }^{10}$ It also allows either party to terminate the contract

4 The kafala system was regulated by Act No. 4 of 2009 Regarding Regulation of the Expatriates Entry, Departure, Residence and Sponsorship.

5 ILO, Observation of the Committee of Experts on the Application of Forced Labour Convention, 1930 (No. 29) - Qatar, 104th ILC session (2015).

6 Ibid.

7 General Assembly of United Nations, Report of the Special Rapporteur on the human rights of migrants, François Crépeau, A/HRC/26/35/Add.1, 23 April 2014.

8 Amnesty International, "Migrants building a state-of-the-art stadium for the 2022 football World Cup in Qatar are abused and exploited - while FIFA makes huge profits." https:// www.amnesty.org/en/latest/campaigns/2016/o3/qatar-world-cup-of-shame.

9 Loïc Picard, "ILo Committee of Experts Bets on Targeted Cooperation to Address Forced Labor in Qatar," International Labor Rights Case Law 6 (2020): 251.

10 ILO, Observation of the Committee of Experts on the Application of Forced Labour Convention, 1930 (No. 29) - Qatar, 109th ILC session (adopted 2020). 
after the probation period, with notice of one or two months. ${ }^{11}$ Second, Act No. 21 of 2015 Regulating the Entry, Exit, and Residence of Expatriates was amended by the Decree Law No. 19 of 2020, allowing expatriate workers to change the employer after notifying the Ministry of Administrative Development, Labour and Social Affairs (MADLSA). ${ }^{12}$ Given that the kafala system is one of the most pressing issues in Qatar, these amendments are a significant step toward fully eliminating forced labor.

The CEACR was also satisfied with the legislative amendments concerning exit visas. Although Act No. 13 of 2018 suppressed the exit permit requirement only for workers covered by the Labour Act, Ministerial Decree No. 95 of 2019 abolished it for other groups of workers as well, such as migrants working in ministries, the oil and gas sector, or private offices. ${ }^{13}$ Another appreciated change is the abolition of the "non-objection certificate," which allowed employers to submit for MADLSA approval a list of highly skilled workers for whom the exit permit would still be required. ${ }^{14}$ These amendments represent the substantial upgrade of the migrant workers' rights, but monitoring their application in practice is still necessary.

Other pressing issues described in the last two CEACR observations are recruitment fees charged to migrant workers and altering of contracts signed in the sending countries after the workers have arrived in Qatar. Certain progress in this area has been made with the establishment of Qatar visa centers in six sending countries, where the future workers electronically sign employment contracts, which eliminates the risk of contract substitution. The government also made an effort to minimalize the risk of recruitment fees by adding a provision prohibiting such fees to the basic contract that all migrant workers sign. ${ }^{15}$ Despite this effort, and the increased number of inspections in the recruitment agencies, the possibility remains that such fees will be demanded. The CEACR therefore again requested the government to continue to adopt measures preventing recruitment fees.

Unlike in its observation in 2020, ${ }^{16}$ the CEACR does not observe any changes on the issue of passport confiscation and repeats that this abuse has become less common. The progress, however, was made protecting workers from nonpayment of wages. In the previous observation, the Workers' Support and

\footnotetext{
Ibid.

Ibid.

Ibid.

Ibid.

Ibid.

ILO, Observation of the Committee of Experts on the Application of Forced Labour Convention, 1930 (No. 29) - Qatar, 109th ILC session (adopted 2019).
} 
Insurance Fund was described as working only on a pilot and partial basis. It is now, the CEACR notes, fully operational and "allocates a sum equivalent to $60 \%$ of the fees collected for workers' permits to ensure diverse and adequate resources for paying the workers' dues and providing them with support."17 Given that the Fund has already begun to recover workers' entitlements, ${ }^{18}$ it seems that Qatar is on a good path to provide migrants with adequate social security.

\section{Access to Justice and Law Enforcement}

The second part of the CEACR observation focuses on access to justice and law enforcement. In its previous comments, the CEACR evaluated access to complaints mechanisms positively, in particular, the possibility of filing through the ILO office in Doha. ${ }^{19}$ In the latest observation, CEACr published new related data. A total of 24,351 workers filed a complaint from January 2019 through August 2020, significantly fewer than in 2018. ${ }^{20}$ Even though the reasons for this decrease are not given, the decrease is presumably attributable to the lower number of labor law violations. Another progressive step the CEACR noted is the opening of a special MADLSA office, implementing the rulings of the Supreme Judicial Council, and ensuring the prompt completion of labor law proceedings. ${ }^{21}$

It is an obligation of Qatar, as a country ratifying the Forced Labour Convention, to ensure that penalties imposed by law for illegal exaction of forced labor are really adequate and strictly enforced. ${ }^{22}$ The CEACR regularly reminds the Qatari government of this obligation, but progress in this area is still pending. The last two reported cases are from 2018, when two defendants were fined for passport confiscation. Because no other punishment than relatively low fines was an option and no new cases have been communicated, concluding that the standard of law enforcement in Qatar is at the level requested by the Forced Labour Convention is not possible. In the coming years, therefore, proper investigation and prosecution of the suspects, together

\footnotetext{
17 ILO, Observation 2020.

18 The Fund has dispersed QAR13,917,484 (US\$3,823,484) as financial relief to 5,744 workers. ILO, Observation 2020.

19 ILO, Observation 2019.

20 ILO, Observation 2020.

21 Ibid.

22 ILO, Forced Labour Convention, Convention No. 29 (1930), Article 25.
} 
with the application of effective and dissuasive penalties, should be the Qatari government's priority.

\section{Conclusion}

The latest observation of CEACR makes it clear that migrant workers in Qatar are provided with more protection from forced labor than previously. However, some pending issues require the attention of the international community. For example, the CEACR requests the state to keep adopting measures preventing recruitment fees from being charged to migrant workers and warns that law enforcement needs to be much more effective. Nevertheless, it seems that Qatar is on a good track to eradicate the forced labor practices present in the country for such a long time. On the one hand, this Qatar case shows the hidden power of ILO's supervisory mechanisms and their ability to achieve desired objectives. On the other, the timeframe within which these procedures bring results is questioned. Construction for next year's World Cup is nearly complete. It seems fair to say that forces inside the country, desiring to take advantage of forced labor, were successful in pressing the government to delay reforms as long as possible. 